This item was submitted to Loughborough's Research Repository by the author.

Items in Figshare are protected by copyright, with all rights reserved, unless otherwise indicated.

\title{
Travels into print: Exploration, writing, and publishing with John Murray, 1773-1859 [Book Review]
}

PLEASE CITE THE PUBLISHED VERSION

https://doi.org/10.1016/j.jhg.2017.08.001

PUBLISHER

(C) Elsevier

VERSION

AM (Accepted Manuscript)

\section{PUBLISHER STATEMENT}

This paper was accepted for publication in the journal Journal of Historical Geography and the definitive published version is available at https://doi.org/10.1016/j.jhg.2017.08.001.

LICENCE

CC BY-NC-ND 4.0

\section{REPOSITORY RECORD}

Bond, Dean W.. 2019. "Travels into Print: Exploration, Writing, and Publishing with John Murray, 1773-1859 [book Review]". figshare. https://hdl.handle.net/2134/32614. 
Innes M. Keighren, Charles W.J. Withers, and Bill Bell. Travels into Print: Exploration, Writing, and Publishing with John Murray, 1773-1859. Chicago and London, University of Chicago Press, 2015, 392 pages, US\$45 cloth.

Travel and exploration are themes that have long captured the attention of scholars from various fields. Travel narratives in particular have received much attention from literary scholars and cultural historians working in a postcolonial vein. Such studies have often aimed to critically scrutinise the various discourses and tropes found in travel writing, and focussed on how such discourses contributed to, and occasionally challenged, the making of colonial powers. What has received far less attention, however, is the material context in which travel narratives came to be. Yet, as Travels into Print shows, understanding how travel narratives journeyed into print is pivotal for understanding both the significance of their content and their wider cultural import.

In roughly 225 pages, the authors of Travels - each distinguished scholars in their own right — throw open to scrutiny the material and epistemological making of travel narratives. They do so by focussing on non-European works of travel published from about 1770 to 1860 by the London-based House of Murray, the most prominent Anglophone publisher of travel narratives in the period. The authors trace the making of Murray travel books from start to finish: from the planning and motivations for travel, to travellers' in-thefield inscriptive and observational practices, to authors' motivations for publishing upon return, to the publisher's motivations for selecting particular works and negotiating with authors, to the editing and printing of the books, to the ways books were received, to how these processes fed back to shape subsequent journeys of exploration and accompanying 
narratives. In short, Keighren et al. seek to show how 'the world was put into words' (p. 211), and they are highly successful in doing so.

Travels into Print succeeds for several reasons, one of which is methodological. Crucially, the authors bring together and examine themes that have often been treated separately. Historians of geography and science, for example, have focussed more on understanding why scholars travelled, and on the truth claims and scientific context of travellers' published work, than on the material dimensions of book production and audience reception. Book historians, in contrast, have focussed more on reception and the material making of books than on in-the-field travel. In examining these themes together, Keighren et al. integrate recent methodological insights from the history of science and historical geography with those of book history, and in so doing produce a study that genuinely illustrates the benefits of interdisciplinary scholarship.

Travels succeeds as well because it substantiates the authors' claim that matters of authority and credibility were central to the making of travel narratives. From the outset, explorer-authors considered how to present their findings in ways that would best convince the reading public of the veracity of their claims. To achieve this, some travellers, such as the Arctic and Africa explorer George Lyon, positioned themselves as amateurs and emphasised their lack of scientific and literary skills. Others did the opposite and underlined the scientific instrumentation they used (e.g. the arctic explorer John Ross), or stressed the careful, in-thefield observational regimes they employed to acquire factual knowledge (e.g. William Martin Leake, author of Journal of a Tour in Asia Minor, London, 1824). Upon their return, credibility was managed by the Murray firm and its in-house readers— such as John Barrow - through, for example, the strategic editing of travellers' manuscripts and the presentation of title pages in ways they thought might further bolster the credibility of a given narrative, the credibility of the firm, and ultimately increase sales. In illustrating this through 
rich empirical material, Keighren et al. do much to further our knowledge of how credibility and authority were practically forged and negotiated, and thus contribute significantly to debates about knowledge production in the history of science.

Travels also succeeds in its aim to show the historical and geographical contingency of basic terms such as traveller, travel writing, explorer, and author. Who counted as an explorer, and what kind of explorer (amateur, scientific), depended, for example, on their social status, whom they travelled with, the inscriptive and observational practices they used when travelling, and on the sort of narrative they produced in conjunction with the Murray firm. Similarly, Keighren et al. effectively demonstrate that the notion of authorship was always contingent and collaborative, as there were many hands in the bringing of book to market, including go-betweens in the field, the Murray firm's in-house readers, the Murrays themselves, and critical reviewers writing for the periodical press. In so doing, Travels marks a significant contribution to ongoing debates in book history about the notion of authorship, and debates in the history of science about terms such as explorer.

Travels is a well-argued and well organised book that contains little to criticise. That said, the book offers little comparative analysis and focusses on English-language sources. The authors acknowledge this, however, and rightly insist that such comparative work was beyond the scope of their project. Here, there are possibilities for future research. If, as Keighren et al. argue, issues of credibility, authority, and authorship were shaped by varying inscriptive, observational, economic, and political practices, then further studies that examine how travel narratives were made in non-Anglophone contexts could throw even greater light on the geographies of authorship and authority. Moreover, although Travels carefully examines the reception of Murray texts in Anglophone periodicals, there is room for future work on the geographies of reading and reception of Murray texts in non-Anglophone worlds. 
Materially, Travels is—like most University of Chicago Press books-a handsome work. It contains numerous beautiful colour and black and white plates, mostly images and paintings from the Murray Archive. In addition, Travels contains a 59-page, detailed bibliography of non-European travel works published by the House of Murray, a resource that has until now been unavailable.

Stylistically, Keighren et al. effectively blend their prose so that stylistic differences amongst the authors become imperceptible. Travels is indeed a well-written and highly readable work. Its clear prose and logical organisation should make it accessible to a range of readers, from specialists to postgraduate students to undergraduates.

Travels is a thoroughly researched and artfully crafted book that substantially advances our knowledge of travel writing and exploration. With its deft and admirably subtle blending of methodological insights and archival material, it evidences the rewards to be gained from working at the intersection of historical geography, book history, and the history of science. It is, moreover, a landmark contribution to the emerging field of the geography of the book. It deserves to be read widely by those interested in the history travel and exploration, the history of geography, and the history of the book, and the book's reasonable sale price should make this possible. 
